\title{
KOKEILEMINEN, MUUTTUMINEN, TULKITSEMINEN
}

\author{
Ei tullut takkia, tuli viitta. Näin tulkitsen loppusuoralla olevaa \\ Kansan Sivistystyön Liiton ja Työväen Sivistysliiton kokeiluprojektia \\ Aikuinen ja työ (ks. Ulla Puro, Aikuiskasvatus 4/90). Viitta saattaa \\ olla parempi: se hulmuaa vapaasti, sen helma pyyhkii mennessään \\ jotain pölyä sivistystyöstä. Tässä viittoja matkalle:
}

\section{Luovu yhdestä perusasetuksesta}

"'Ei tutkintotavoitteisuutta vapaaseen sivistystyöhön." Tätä perusasetusta en ole aiemmin kyseenalaistanut. Epäilin, että tutkinnot toisivat riskin sopeutua järjestelmiin, niiden mukana tulisi instrumentaalinen lähestymistapa oppimiseen ja opintokerhojen itsenäisyys vähenisi.

Aikuinen ja työ -opintoprojektissa on unohdettu tutkintotavoitteisuuden vastustaminen. Tutkintoon ei tosin hypätty suoraan. Tarkoituksemme oli vain katsoa, miten opintokerhoissa voidaan toteuttaa vaativaa ja pitkäjänteistä opiskelua. Välittävänä ideana oli englantilainen versio yliopistotasoisesta sopimusopiskelusta (ks. esimerkiksi Dave O'Reilly, 1989). Kokeilun tarkoituksena on tältä osin selvittää:

- mitä mahdollisuuksia on sille, että opintokerhoissa voidaan suorittaa yliopistolliseen arvosanaan verrattavia opintoja opiskelijoiden itsensä laatiman opintosuunnitelman mukaisesti

— mitä merkitystä opiskelun edistymiselle ja laadulle on sillä, että opinnot tuottavat arvosanasuorituksen ja todistuksen siitä.

Aikuinen ja työ -tutkinnossa on KSL- ja TSLopintokeskuksissa laadittu kehysosa, johon kuuluu johdatus tietoon ja työelämän rakenteisiin, kirjallista ja suullista viestintää sekä loppukirjoitelma, yhteensä 3,75 opintoviikon verran suorituksia. Lisäksi tutkintoon on sisällytetty opintoja avoimessa korkeakoulussa useimmissa tapauksissa 15 opintoviikon verran.

\section{Löydä toisia motivaatioita}

Aiemmin olen ymmärtänyt emansipatorisen intressin (Habermas) osaksi perinteistä opintokerhoideologiaa: ihmiset oppivat yhteistoiminnallisesti uutta voidakseen yhdessä käyttää uusia taitojaan ja kykyjään yhteiskunnallisessa toiminnassa. Tässä projektissa alan lukea tuota intressiä toisin: itsensä ylittämistä vaativassa opiskelussa opintokerho on tukenut opiskelijoita kriittisessä toiminnassa niin, että kerholaiset ovat käyttäneet opiskeluaan esimerkiksi oman työpaikkahierarkian näkyväksi tekemiseen ja uudelleentulkitsemiseen. Erityisesti tutkintoon kuuluva lopputyö antaa tilaisuuden reflektoida kokemustaan ja työpaikkaansa.

John Stephenson (1990) löysi englantilaisilla yliopistotason sopimusopiskelijoilla kuudenlaisia primäärejä motivaatioita: arvostuksen ansaitseminen, identiteetin etsiminen, (oman) arvon osoittaminen, sitoutumisen rakentaminen, pätevyyden hankkiminen ja elämän muuttaminen. Stephenson olettaa, että tällaisia tarpeita on löydettävissä mistä tahansa opiskelijajoukosta. Kokeilumme tutkimusosuus tulee vastaamaan tähän kysymykseen, mutta jo nyt on selvää, että Aikuinen ja työ -tutkinto on ollut aivan uudenlainen mahdollisuus työssäkäyville, usein puutteellisen pohjakoulutuksen omaaville ihmisille.

Tutoroidessani kolmea ryhmää olen havainnut, että korkeakoulutason opinnot antavat tilaisuuden osoittaa pärjäävänsä, ansaita arvostusta esimerkiksi omien lasten silmissä. Siitä kertoo myös riemu tenttituloksista. 


\section{Näe (uudelleen) matka kirjoitettuun diskurssiin}

Ennen kuin aloin kirjoittaa tätä, selailin automaattisesti Aikuiskasvatus-lehden numeroita, ilmeisesti tehdäkseni "tilapäisteorian" (Donald Davidson via Richard Rorty, 1989) tässä lehdessä käytettävistä sana- ja kuvamerkeistä. Kirjoitan nyt sen teorian varassa tietynlaiseen kontekstiin, hakien siihen sopivia metaforia. Luon kirjoitettua kokemusta, kirjoitettuun kontekstiin. Jos joku vastaa kirjoitukseen, voin korjata tilapäisteoriaani ja ehkä löytää kontekstiin osuvampia merkkejä. Suosikkiongelmani tutorina on ollut löytää keinoja kontekstin tekemiseksi näkyväksi. Kokeiluprojekti on antanut hyvin konkreettisen näkökulman siihen, mitä on matka ajattelusta kirjoitettuun ajatteluun. Kerho saattaa raportoida käyneensä monitasoisen ja -tahoisen keskustelun. Etätehtävän vastauksessa se kuitenkin on kirjoittunut yksiulotteiseksi kapulakieleksi, pariksi lyhyeksi lauseeksi. Mitä tuossa keskustelussa on tapahtunut? Tavoitettaisiinko se, jos ryhmäkohtaiset etätehtävät kirjoitettaisiin näytelmiksi?

Satunnaisesti seuratessani keskustelua tekstistä totesin, että tekstiä pidettiin alkurepliikkinä, josta itse kukin assosioi omia kokemuksia ja keskittyi puhumaan niistä. Myös etäopiskelutehtäviin opintokerhot saattoivat tehdä kuin keskustelurepliikkejä. Vain hitaasti löytyi keinoja laajentaa kirjoittamista, ja vasta "prosessikirjoittamisen" tekniikka näytti opiskelijoille mahdollisuuden käyttää opintokerhoa oman tekstinsä kehittämiseen. Rajoituksensa silläkin: useilla opiskelijoilla tässä projektissa ei ole konekirjoitustaitoa.

\section{Laajenna oppimisen strategian käsitettä}

Kokeilua suunniteltaessa perehdyimme tutorointia koskevaan kirjallisuuteen ja kuulimme luentoja aiheesta. Paitsi että olemme nyt kokeilevasti luoneet omia tutorkäytäntöjämme, tutoreina on meillä ollut mahdollisuus tutkailla aikuisten oppimisen strategioita.

Oppimisen strategioista puhuttaessa tarkoitetaan tavallisesti vuorovaikutusta oppimisen kohteen kanssa, kuten pinta- tai syväprosessointeja. Aikuinen ja työ -opiskelijoita tutoroituani olen sitä mieltä, että metakognitiivisiin taitoihin on syytä liittää "'metaemotionaaliset", eräänlainen emotionaallinen kompetenssi. On hyödyllistä auttaa oppijaa tulemaan tietoiseksi koko lähestymistavastaan oppimiseen: miten luoda toistuvasti resursseja antava mielentila, miten tuottaa omaa oppimista koskevia positiivisia uskomuksia ja positiivisia, itseään toteuttavia ennusteita, miten luoda suhde kulloiseenkin kohteeseensa, mi- ten "'merkitä" erilaisia muisti- ja pohdintatehtäviä aivojaan varten, miten käyttää alitajuntaansa oppimiseen. Näin oppimisen strategia laajeneekin yleiseksi muutosten strategiaksi.

Erityisesti suggestopediasta ja neurolingvistiikasta löytyy tulkintoja kokemiini tapahtumiin opiskelujen onnistumisista ja tukkiutumista. Pelkästään kuuntelemalla opiskelijoita saatoin kartoittaa, miten he suggeroivat itseään positiivisesti ja negatiivisesti. Filosofiasta saattoi opiskelija tehdä itselleen tosi vaikean vain toistelemalla itselleen, kuinka älytöntä se kaikki oli.

Esimerkiksi Robert Dilts on kuvannut erilaisten muutosten loogista hierarkiaa siten, että alimpana hierarkiassa ovat yksittäiset, ympäristöön kohdistuvat osaamiset, jotka erilaisina yhdistelminä liittyvät seuraavaan ylempään tasoon, taitojen ja kykyjen tasoon. Yksittäisiä osaamisia näytti opiskelijoiden olevan suhteellisen ongelmatonta harjoitella ja hallita. Mutta monimutkaisempien toimintojen - mitä esimerkiksi omien pohdintojen kirjoittaminen tai tilastojen arviointi on - harjoittamisessa esteeksi nousi yhä uudelleen jokin suurempi, usein jokin "meikäläisyys".

Taitojen ja kykyjen omaksumisen tai muuttumisen edellytyksenä Diltsin mukaan on, että yksilön uskomukset ja arvot, jotka ovat hierarkiassa ylempi taso, sallivat sen. Eli oppimista koskevat uskomukset joko sallivat oppimisen tai säännöstelevät sitä negatiivisessa mielessä. Yksilön uskomukset ja arvot puolestaan kiinnittyvät identiteettiin. Ylimpänä hierarkiassa on "jumalataso", jonka yksilö voi kokea Jumalaksi tai muunlaiseksi eettiseksi periaatteeksi. Ylin taso ohjaa yksilön "tehtävää maailmassa" ja siinä mielessä rajaa hänen mahdollisia muuttumisiaan ja myös oppimisiaan.

Diltsiläinen muutostasojen hierarkia viittaisi siihen, että tehokkaat oppimisen/muuttumisen strategiat ovat systeemisiä ja sisältävät hierarkian eri tasoilla toisistaan paljonkin poikkeavien muutosedellytysten luomista. Mikä haaste tutoreille!

\section{Törmää hierarkioihin}

Kun Aikuinen ja työ -tutkintoa suunniteltiin, ajatuksena oli koota siihen yksilöllisiä sisältöjä yhdistelemällä avoimesta korkeakoulusta osioita vapaasti eri tieteenaloilta.

Ankea totuus tietenkin on, että yliopistot ovat osa yhteiskunnallista hierarkisointia. Niiden sivistyksellinen tehtävä on alistettu erilaisille karsinta-, legitimointi- ja reviirinmuodostustehtävil- 
le. Avoin korkeakoulu niiden liitännäisenä liikkuu siis varsin ahtaassa urassa. Ennen kaikkea monimuotosovelluksia on vähän.

Yksilöllisten mosaiikkien sijasta päädyimme tarjoamaan korkeakoulutasoista opiskelua aikuiskasvatuksessa, jossa Lahden tutkimus- ja koulutuskeskus hankki projektia varten oman opettajan hoitamaan opetusta sähköpostin kautta.

Aikuiskasvatus sopi kylläkin projektiimme ja tarjosi seikkailua yllin kyllin. Mutta alkuperäinen ideamme opintosuunnitelmien yksilöllisyydestä kapeni toteutuksessa. Vain pieni perhepäivähoitajien ryhmä siirtyi toisena vuonna opiskelemaan erityispedagogiikkaa, muut jatkoivat aikuiskasvatusta. Oliko kyseessä opiskelijoiden sopeutuminen järjestelmään vai alkoiko aikuiskasvatus aidosti kiinnostaa? Ainakin muutamat ovat kertoneet jatkavansa aikuiskasvatuksen opiskelua.

\section{Jatka etsimistä}

Tämä kirjoitus on projektin lopulta, tiivistelmät ja kokonaistulkinnat odottavat tekemistään. Projekti on jo ehtinyt muuttaa molemmissa kokeilevissa opintokeskuksessa olevia käytäntöjä.
Uusi tutkinto TSL:n, KSL:n, ammattiliittojen ja ay-opistojen yhteistyönä on valmisteilla. KSL:n ja Vasemmistoliiton organisoimina ovat lähteneet liikkeelle Minä, Vasemmisto ja politiikka -opinnot, joissa yhdistetään sopimusopiskeluidean mukaiset yksilölliset oppimissuunnitelmat, oppivat ryhmät ja tutorointi.

\section{VIITATUT LÄHTEET}

Robert Dilts, Changing Belief Systems with NLP, Meta Publications 1990

Dave O'Reilly, Yksilölliset opinnot ja sopimusopiskelu, Luento TYT:n symposiumissa Tampereella 22.8.1989

Ulla Puro, Aikuinen ja työ -opinnot monimuotoisena ryhmäopiskeluna, Aikuiskasvatus 4/90

John Stephenson, The Student Experience of Independent Study, Inaugural Professorial Lecture February 6th

1990, Polytechnic of East London

Richard Rorty, Contingency, irony, and solidarity, Cambridge University Press 1989 